\title{
Role of Business Incubation in Sustaining Small and Medium Enterprises in the Kingdom of Eswatini
}

\author{
Thobile Makhosazana Dlamini ${ }^{1}$, Oyebanjo Ogunlela ${ }^{1} \&$ Chux Gervase Iwu ${ }^{1}$ \\ ${ }^{1}$ Department of Entrepreneurhip and Business Management, Cape Peninsula University of Technology, South Africa \\ Correspondence: Chux Gervase Iwu, Department of Entrepreneurhip and Business Management, Cape Peninsula \\ University of Technology, South Africa. E-mail: iwuc@cput.ac.za
}

Received: June 27, 2020

Accepted: August 10, 2020

Online Published: December 20, 2020

doi:10.5430/rwe.v11n6p247

URL: https://doi.org/10.5430/rwe.v11n6p247

\begin{abstract}
What do business incubators do? Do they play a significant role in enhancing the entrepreneurial competitiveness of small and medium enterprises (SMEs)? Could they play any significant role in the development of SMEs? What are the types of entrepreneurial skills and strategies offered by business incubators in the Kingdom of (Note 1) Eswatini? These are the pertinent questions that were taken on in this paper through a desktop literature analysis, to understand the role and impact of business incubators. Themes that emerged helped to gain better insight into the roles of business incubators as well as how they overcome identified challenges. This paper concludes that further study on the role of business incubators in Eswatini may take the form of an extensive, statistical approach using empirical data to unearth business incubators' impact on SMEs' competitiveness and sustainability. Further to this, it is suggested that available frameworks and policies from other successful countries be examined for the benefit of the Kingdom of Eswatini.
\end{abstract}

Keywords: business incubators, sustainability, small and medium enterprises (SMEs), entrepreneurs, incubation, Kingdom of Eswatini

\section{Introduction}

The importance of small and medium enterprises (SMEs) cannot be overemphasized, because of the role they play in helping to enhance economic development. They catalyze job creation and the economic development of a nation (Fatoki, 2014). Also, Choto (2015) corroborates the assertion that when SMEs are adequately supported and a conducive business environment is provided, these small enterprises contribute to job creation and economic development. Despite this important role played by SMEs in job creation, it is unfortunate that the rate of failure of both start-ups and existing businesses is alarming (Lose \&Tengeh, 2015). To help reduce this challenge, Business Incubators (BIs) play a crucial role in helping to nurture these businesses to a point where they are self-sustaining. Globally, it is confirmed that BIs help to provide an avenue for the training and guidance of SMEs, for them to remain in business after take-off (Lose \&Tengeh, 2015); this process, however, involves a substantial investment. Furthermore, they serve as a strategic tool that assists a country to grow its entrepreneurial base, aid in reducing the high mortality of SMEs, and subsequently, result in poverty reduction within an economy (Masutha \& Rogerson, 2014; Ogutu \& Kihonge, 2016). An attempt has been made in the literature to define business incubation; according to Hughes, Ireland, and Morgan, (2007: 155), BI is "a facility that houses young, small firms to help them develop quickly into a complete business." Additionally, the Entrepreneur's Small Business Encyclopaedia (Business incubator, 2020) defines a BI as "an organization designed to accelerate the growth and success of entrepreneurial companies through an array of business support resources and services that could include physical space, capital, coaching, common service, and networking connections". Globally, business incubation is becoming an important policy instrument aimed at enhancing local economic development (OECD, 1999).

Arising from the foregoing, there is no question as to whether BIs have a role to play in augmenting entrepreneurial competencies and competitiveness, as well as the sustainability of SMEs. The major concern seems to be to what extent BIs enhance the competitiveness and sustainability of SMEs. Business incubation was developed by various nations in response to industrial restructuring. This is to help reduce the socio-economic impact caused by the closure of manufacturing facilities or outdated technologies (OEDC, 1999). Wanyoko (2013) iterates that there has been a proliferation of BIs since their inception almost half a century ago, which has evolved into the creation and 
development of many practices that could enable effective running of operations. These practices, according to Bruneel, Ratinho, Clarysse and Groen (2012), can be divided into three main categories, namely (a) first generation where BIs provide office or workspace and share essential resources for SMEs to enjoy economies of scale; (b) Second generation - BIs play the role of coaching and training support, to help accelerate the knowledge curve of enterprises being incubated; (c) Third generation - providing access to technology, professional and financial networks, resulting in entrepreneurs who have the legitimacy to external resources and knowledge.

In many parts of the world BIs are fast becoming a policy instrument used to promote employment opportunities and economic growth through SMEs (OECD, 1999); thus, prompting taking on this initiative. While in some developed countries, BIs have been around for a long time, this initiative is still very new in other countries. Despite the growing interest in BIs and its importance in helping SMEs to strive globally, in addition to the numerous opportunities these processes could offer SMEs, there are, unfortunately, a host of challenges that could impede the operations of BIs, thereby preventing them from achieving their set objectives (Schwartz \&Hornych, 2010). In the Kingdom of Eswatini, SMEs are faced with numerous challenges in helping to contribute to the socio-economic development of the nation, nevertheless, BIs have been able to come to the rescue through their assistance in nurturing SME sustainability. The literature further iterates the importance of SMEs in economic development (Abor \& Quartey, 2010) and job creation (Gwija, Eresia-Eke \& Iwu, 2014).

It is argued by FinScope Swaziland (2017) and Makhubu (2017) that, most new businesses in the Kingdom of Eswatini are not sustainable because they go out of business within the first two years of their existence, thereby necessitating the need to determine the challenges and problems confronting their continued existence. Unfortunately, Arubayi (2010) and FinScope Swaziland (2017) posit that even with the assistance of BIs, these SMEs still do not remain in business for a long time. Therefore, the immediate question that comes to mind, which this review tried to answer is: What kinds of entrepreneurial skills and strategies are offered by BIs in the Kingdom of Eswatini?

Interestingly, several studies such as those of Dlamini, Masuku, and Dlamini, (2008), Hlatshwako (2012) and Dlamini (2016) examined the support, needs, and challenges of SMEs in the Kingdom of Eswatini, yet none addressed the importance of the entrepreneurial skills of the business incubator services in the Kingdom of Eswatini.

This paper is organized as follows. We explain the methodology adopted in writing this paper. Immediately following this is a review of literature on what BIs are, after which business incubation in the Kingdom of Eswatini is discussed. Thereafter, the types and roles of BIs, as well as why start-ups need business incubation in the Kingdom of Eswatini are examined, followed by key performance indicators of enterprises after incubation, the study limitations, and lastly, the conclusion and implications.

\section{Methodology}

This study intended to draw attention to the necessity of BIs in shaping and growing SMEs. In doing that, we focused particularly on the Kingdom of Eswatini which is plagued by high unemployment and poverty. To achieve the goal of this study, a qualitative approach that involved the review of existing literature was followed (e.g. Opute et al. 2020). Given its suitability, a descriptive literature survey method was adopted specifically owing to its capacity for discerning previous research that closely aligns with themes of a research project. Thus, in this case, using keywords, essential secondary data was uncovered which helped to form the thesis of the study. Thus our review strategy was to gather robust evidence on the central theoretical themes for this study as that would allow for systematic and transparent methods to identify, select, and evaluate relevant literature relating to a specific topic or question (e.g. Cronin, Ryan \& Coughlan 2008; St. John \& McNeal, 2017). We ended up deriving a construed and substantive demonstration of the need to first acknowledge the significance of BIs in SME growth and development; the necessary conditions for BI performance and overall benefit to an economy.

To ensure that knowledge is captured accurately, an iterative approach that involved reading the text back and forth was used (e.g. Straus \& Corbin, 1998). Following the central aim of this review, data abstracted were in the form of conceptualization of ideas or theoretical perspectives (Snyder, 2019). Essentially, with the data we selected and analyzed, we were also able to draw conclusions and implications concerning our key objective. Areas for future research are also flagged.

\section{What Is Business Incubator?}

Business incubation is gaining attention globally as a field of research, because of its importance and its ability to help grow business innovatively and competitively (Fernández Fernández, Blanco Jiménez \& Cuadrado Roura, 2015). According to the National Business Incubation Association (NBIA, 2001), BI is defined as a "dynamic process of business enterprise development and a business support process that accelerates the successful 
development of start-up and fledgling companies by providing enterprises with an array of targeted resources and services". Further to this, Al-Mubaraki and Busler (2011:2) mention that, "these services are usually developed or orchestrated, by the business incubator and through its network of contacts". The European Commission (as cited in Fernández, Fernández \& Blanco Jiménez, 2011: 162), in its benchmarking of BIs, iterates that a BI is "an organization that accelerates and systemizes the process of creating successful enterprises by providing them with a competitive and integrated range of support including incubator space, business support services, and clustering as well as networking opportunities...", and that BIs 'significantly contribute to the survival and growth prospects of new start-ups'. Furthermore, Sherman and Chappell (1998: 313) had previously defined BIs more explicitly, covering a wide range of activities relating to development as an

“...economic development tool primarily designed to help create a new business in a community. They assist emerging business through the provision of many support services ranging from, assistance in developing business and marketing plans, building management teams, obtaining or sourcing for capital, and access to a range of professional services, as well as flexible space, shared equipment, and administrative services".

The role of BIs was further corroborated by Aernoudt (2004), who mentioned that, apart from providing space, an incubator should assist in the provision of prerequisite training and skills development, sourcing of funds, legal assistance, and operations management, as well as launching into new markets. Therefore, it can be inferred that BIs assist in providing an environment where new start-ups can commence their business under the watchful eyes of BIs, in a manner where they are 'protected' from unfriendly market competition, until when they can stand on their own. This is important due to management and staff of most start-ups not having the necessary skills and resources required to 'hit the ground running' immediately after they begin operation. According to Barrow (2001), it is posited that BIs predominantly provide three types of resources to new business ventures, namely infrastructure, business support, and access to a network of professionals.

The history of BI dates back more than 50years, starting in the United States of America (USA) in 1959, with the first BI incorporated in Batavia, New York, as a privately owned for-profit organization (Brown, Harrell \& Regner, 2000). Over the years, the role and establishment of BIs have gained prominence and according to the National Business Incubation Association (NBIA, 2014), approximately 7000 BIs exist globally, whereas in the 1980s only 12 BIs were in existence in the USA, with this number having increased tremendously over the years to about 1250 in 2012. This astronomical rate of establishing BIs has been linked to the ability in helping to support the establishment, support, and growth of SMEs in developed and developing nations (Mahmood, Jianfeng, Munir, Yanran \& Cai, 2016).

\section{Business Incubation in the Kingdom of Eswatini}

The Kingdom of Eswatini has an open economy with most of its exports and imports traded with South Africa as a result its currency, the Lilangeni (SZL), is pegged to the South African Rand (SZL1: ZAR1). In 2018, the South African economy experienced a technical recession in the second quarter, which caused a deceleration in Eswatini's export demand, mainly destined for the South African market (CBE, 2019). Economic activity, measured by real Gross Domestic Product (GDP), is estimated to have grown by 0.6 percent in 2018 . The 2018 estimates are based on the GDP Projections by the Macro-Forecasting Team of the Ministry of Economic Planning Department (MEPD) and the Central Bank of Eswatini (CBE, 2019).

Amongst other entities, the economy is driven by receipts from the South African Customs Union (SACU), Common Market for Eastern and Southern Africa Development Community (COMESA), South African Development Community (SADC), and the European Union (EU), as well as the Africa Growth and Opportunity Act (AGOA). The domestic market is dominated by the public sector but the ministry of commerce, industry, and trade (MCIT) is presently working on policies to develop SMEs in the country (Dlamini, 2018).

In 1970, the Kingdom of Eswatini embarked on development policy through the formation of the Small Enterprise Development Company (SEDCO) which provides infrastructure and business development services; registration of start-up ventures, coaching, and training on business management (MCIT, 2014). SEDCO incubates a variety of SMEs. According to the SEDCO data bank of August 2018 (SEDCO, 2019), the SME sector includes textile, building construction, and woodworking, along with manufacturing of soap and non-edible oils, as well as restaurant/butchery and miscellaneous businesses. The incubation process starts with enterprises applying for incubation (incubates) to being accepted into the controlled conditions, which are meant to guide and protect the infant businesses, until their graduation. The establishment and encouragement of new businesses in a community is the main goal of BIs. In assisting entrepreneurs to start new businesses, the community enjoys benefits of increased 
employment opportunities, additional revenue, and prosperity (Sanyal \& Hisamic, 2018).

In 1999, Eswatini Water Agricultural Development (ESWADE) was established (ESWADE, 2019). This is an example of BIs second generation evolution; they empower communities to improve their quality of life through commercial agriculture. ESWADE incubation focuses on registration and training of legally operating agri-business schemes, for sugarcane production, farming of alternative crops, as well as livestock enterprises. Following the construction of a dam in a chiefdom or community, the population of the project area is trained to effectively use the irrigation infrastructure provided to establish sustainable agricultural businesses.

Representing BIs third-generation evolution in the Kingdom of Eswatini is The Royal Science Technology Park (RSTP), which started operating in 2017. The RSTP is a platform for research and development in Information Technology (IT), production of high tech products, marketing, and trading (Sebenzile, 2018). RSTP nurtures innovation start-ups in electronics, communication technology, value-added agriculture, and renewable energy, as well as environmental management, health, and beauty (RSTP, 2019). This BI offers office space, which includes IT equipment, along with business development processes, fundraising support, and technical support for innovation development and validation. RSTP's objective is to help enterprises survive and grow through the vulnerable primary stages of business initiation, to become bankable and competitive businesses. In the Kingdom of Eswatini, the main incubation organization is the Small Enterprise Development Company (SEDCO), which operates within the MCIT. The purpose of this arm of government is to sustain and stimulate the small business sector in the country. SEDCO's main services are tailor-made training programs and very low rental premises available in most of the cities and towns of the country (SEDCO, 2019). Apart from lowering running costs, the provision of physical incubation contributes to helping enterprises being incubated with a network of individuals; purchasing from one another, and assisting each other.

\section{Types of Business Incubators}

Different BIs exist and can be classified according to the owners and intention of the BI as follows:

\subsection{Public Business Incubators (PBI)}

These are BIs owned by public corporations that assist start-ups with relevant infrastructures, space, provision of technical and managerial assistance, development of a business plan. The motive of this type of BI is to assist in the reduction of costs incurred by the new organization, thus, PBIs only make their money from the cost of services provided, as well as funding received from local, national and international government support initiatives (Grimaldi \&Grandi, 2003).

\subsection{University Business Incubators (UBI)}

This is a type of BI which is set up by universities to assist in research and development (R\&D) of entrepreneurial initiatives that could lead to spin-off enterprises from the university to become fully-fledged organizations, whilst still being supported by the university. Furthermore, these UBIs are similar to the conventional PBI; however, they differ in that they focus more on technology transfer through innovation and research to organizations. The activities of UBIs can, according to Grimaldi and Grandi (2003) be classified into two broad categories: provision of incubation services such as infrastructure, sourcing, and raising of funds, provision of business support, and networking, as well as other relevant support services; and secondly, serving as consultants, helping to provide access to library and laboratories, conducting $\mathrm{R} \& \mathrm{D}$, training and knowledge transfer, in addition to access to computing facilities.

\subsection{Private Business Incubators (PrBI)}

These are BIs specifically set up to make a profit through collaboration with start-up companies. According to Hansen, Chesbrough, Nohria, and Sull (2000), the Harvard Business School mentioned that approximately 356 of these BIs exist in the USA, with approximately $92 \%$ being internet-focused corporations. Nevertheless, Hansen et al. (2000) further iterated that a substantial number of these PrBIs are also new companies that experience difficulties raising start-up funds, in the same manner, new ventures do. PrBIs can make a profit through service charges and by taking a percentage of the revenue generated by the enterprises under incubation (Hansen et al 2000). Moreover, the PrBIs assist start-ups through business guidance, networking with their contacts, office management, and also by helping to shape their business model to accelerate product development and access to required technology. PrBIs are classified into two categories: Corporate BI and Independent BI. Corporate incubators are established organizations that provide the necessary facilities and mentoring of start-ups; this usually starts from internal projects within the organization. Subsequently, these corporate incubations will often lead to spin-offs, as a result of business diversification, while the individual BIs are established through a single or a combination of individuals with a focus 
on assisting their business, making use of their capital to help grow the business and then acquiring a share of the organization.

\subsection{Technology Business Incubators (TBI)}

According to the Organisation for Economic Co-Operation and Development (OECD, 1997: 4) Technology BIs (TBIs) are

"a specific type of $\mathrm{BI}$ : property-based ventures which provide a range of services to entrepreneurs and start-ups, including physical infrastructure (office space, laboratories) management support (business planning, training, marketing), technical support (research, database), and access to financing (Venture capital funds, business angel networks), along with legal assistance (Licensing, intellectual property) and networking (with other incubators and government services); they assist with technology know-how to help accelerate the development of business initiatives to enhance commercialization of technology-based business."

Lastly, there is a new type of BI referred to as a Research Park or Science and Technology Innovation Centre, which has also been seen emerging in the business incubation industry. A science park is an organization whose aim is to encourage innovation, high technology production, and competitiveness of associated businesses. This is for the creation and growth of innovation-based companies (UNESCO, 2019).

\section{Role of Business Incubators}

The objective of BIs is to help in the speedy development of sustainable entrepreneurs and organizations (start-ups), through the provision of necessary support services by the BIs and their array of networks, to become sustainable. Some of the services rendered by BIs, according to Lesáková (2012), vary from one BI to the other in the manner services are being provided; based on the type of services and customers, as well as the structure of the organization. This was corroborated by Niammuad, Mapompech, and Suwanmaneepong (2014), who argued that BIs provide different types of facilities, ranging from those that are technology-focused, while others are mainly focused on business development. Nevertheless, these BIs' roles are almost the same, since they both provide business development support to start-ups through training, managerial support, office space, and infrastructure, in addition to other facilities, along with technology transfer, assistance in helping to reduce the time to market, consulting services, networking and raising of requisite funds to help grow the new business (Van der Zee, 2007; Koshy, 2010). Furthermore, BIs also assist in encouraging the start-up of new business within an environment, thus leading to the provision of employment opportunities within the local environment, and by extension, economic development of the nation (Lesáková, 2012), while assisting with the provision of funds, skills and numerous resources to start and run a business until it becomes profitable.

\section{Why Do Start-ups Need Business Incubators in the Kingdom of Eswatini?}

Mahmood, Jianfeng, Munir, Yanran, and Cai (2016) explained that BIs can assist in nurturing and growing small and medium enterprises (SMEs) from the nascent stage, until they can stand on their own, thus helping to solve economic problems through job creation and contributing to the economic development of a nation. Bowen, Morara, and Mureithi (2009) iterate that BI is perceived to be the "magic bullet" that would assist entrepreneurs to reduce the failure rate of new business ventures, most especially since it is estimated that roughly $70 \%$ of SMEs fail in their first year of establishment. Therefore, to avoid or reduce this failure rate, BIs help to provide the necessary guidance and services for SMEs to remain in business.

Sustainability of SMEs has been confirmed to contribute to economic development in developed nations (Iwu, 2018). It can then be argued that any government that provides a conducive business environment as well as the necessary support through BIs, tends to also improve the economies of their nation through job creation, thus helping to reduce socio-economic problems and poverty (Ayyagari, Beck, \&Dermirguc-Kunt, 2011). BIs are evolving to meet challenges faced by SMEs globally through innovation. Unfortunately, the Kingdom of Eswatini is largely faced with a lack of innovation and creativity that could enhance business sustainability (RSTP, 2019), which creates obstacles for BIs to render their services effectively incapacitating SMEs. The challenges faced by entrepreneurs in the Kingdom of Eswatini and the importance of BIs in helping to overcome these are discussed in the section below.

\subsection{Facilitating Entrepreneurial Skills}

To cope with sudden business changes, new firms need to have the necessary management and entrepreneurial skills to start and sustain their business, unfortunately, the opposite is the case in most developing countries in general and the Kingdom of Eswatini in particular. Gwija et al. (2014) in their study, noted that education and training in entrepreneurship could positively contribute to the success of any business. The developed routine through 
experiential practice reshapes the operation of a start-up venture. Coaching and training services provided by BIs are likely to help start-up ventures avoid the long progression of trial and error as they learn by doing (Bruneel et al., 2011). Gwija and others further suggest there should be a change in the education system, having entrepreneurial skills being taught to high school and university graduates. The essence of this is to equip most graduates with the necessary skills to be employers of labor, instead of seeking employment post-graduation. This assertion was confirmed by Dlamini (2018), who argued that most SMEs in the Kingdom of Eswatini are faced with the challenge of business sustainability, due to the lack of entrepreneurship training, skills and culture.

\subsection{Provision of Strategic Support to Equip SMEs}

Despite the challenges of SMEs, the sector still has success stories. To some, success comes quickly due to certain strategies while for others, success comes after having gone through challenges and failures. Acquiring business funding is a challenge to most SMEs, not just in Eswatini but in many emerging countries. Aspiring entrepreneurs in Khayelitsha, South Africa, who cannot afford to raise capital, due to a lack of funding, opt for paid jobs (Gwija et al., 2014). Unfortunately, this includes graduates who have acquired entrepreneurship education from the university. The CEO of Finfind, Menzies (2019), acknowledges that access to funding is crucial for business sustainability and growth but sadly, many SME owners lack the skills required to identify the right funders and the appropriate financial products. Wanyoko (2013) determined that approximately $50 \%$ of respondents, in his study on the role of business incubation services in supporting the growth of SMEs in Kenya, confirmed they were able to access required funds for their business through an incubation program. Nevertheless, some SMEs still struggle with raising funds or gaining access to the necessary funds to start or sustain their business, despite numerous opportunities available to them. This is because they lack the requisite skills or strategies necessary to help them access funds. As such, it is important to note that education alone does not give the assurance that entrepreneurs can access funds; they must also possess skills and expertise on how to operate their businesses.

\subsection{Management of Internal and External Dynamics of the Organisation to Enhance Success}

Some factors leading to the failure of SMEs can be attributed to both internal and external challenges. According to Fatoki (2014), internal factors are mainly controlled by the organization and are related to the organization's management and everyday working skills (planning, organizing, leading, and controlling). However, organizations do not have much control over external factors because they emanate from the external environment. Amongst many others, external factors include infrastructure, escalating costs of doing business, competition, and crime. It is therefore of great importance for an entrepreneur to know what needs to be done to persist in the competitive market. The following are essential strategies for new ventures to succeed:

\subsubsection{Business Information}

For survival and growth, relevant business information such as sources of inputs, availability of markets, and regulatory policies are important. Gaining access to relevant business information by SMEs also depends largely on the entrepreneur's level of education, social networks, and infrastructure qualities. According to Fatoki and Odeyemi (2010), for SMEs to acquire funding, it is essential to have access to pertinent facts that meet the needs of that particular investor. Education and learning are some of the key elements of a new entrepreneur's success. Using a consultant to write up a business plan for an entrepreneur could help secure funding but it is likely to be counterproductive. When an entrepreneur is solely responsible to gather the pertinent information and write the business plan, this will not only enable the entrepreneur to confidently articulate the proposed plan, it also allows the entrepreneur to learn more about the industry and how to run a successful business venture.

\subsubsection{Marketing}

The main marketing variables are establishing the right price for a product, having effective product demand, the business being in the right location, and having knowledge about the target market where the products can be sold (Cant \& Wiid, 2013; Iwu, 2009). Not taking cognizance of these factors at business initiation may serve as a limitation to the business' success. A business exists to make a profit and become sustainable through the provision of products or services to their niche markets, with most big corporations understanding this. As such, these large businesses employ staff to serve as relationship staff, to deal with customer requests, and to identify new markets. Should this be lacking, the business may not be able to achieve its set objectives. The practicalities of marketing support in an incubation program are important because, according to Strydom, Ferreira, and Nieuwenhuizen, (2010), SMEs with minimal marketing resources and a deficiency in technical resources are most likely to miss out on large, readily available markets. Further, Strydom, et al. (2010) iterate that the marketing skills of SME owners determine whether the business will succeed or go under in the long-term. 


\subsubsection{Human Capital}

Human capital refers to the expertise of a human being in producing commodities and is influenced by education, skills, talents, and experience, as well as values and social influences. Entrepreneurs with proficiencies in business management, finance, operations, and marketing in addition to human resources, are likely to be successful at start-up (Sin, 2010). Unger, Rauch, Frese, and Rosenbusch, (2011) noted that the human capital theory was originally a business estimation for employee compensation, however, it has since been adopted by entrepreneurship researchers as a prediction model for entrepreneurial success. An entrepreneur with highly rated human capital skills is most likely to easily organize and coordinate resources to exploit opportunities. Having a better understanding of the particular requirements of existing resources and prospects allows for business persistence (Sin, 2010). Fatoki (2014) highlighted the importance of networking skills and its ability to help build relationships, not only with current suppliers and customers but also with potential future business stakeholders. In an informal interview with a bank official, Fatoki mentioned that new SME owners with previous banking relationships are most likely to be successful in applying for a start-up loan. Fatoki further stated that, as a business evolves to higher growth stages, the founding entrepreneur reaches a maximum, where it becomes critical to be replaced by professional managers or it is more apt to fail. Some BIs offer facilities to start-up businesses whilst being part of an incubation program. Social relationships may be activated amongst incubated peers; sharing information and being coaches to each other could help a firm to learn appropriate behaviors that can be used to obtain needed support.

\section{What Are the Key Performance Indicators of Incubated Enterprises After Incubation?}

Many performance indicators have been used to analyze the effectiveness or performance of organizations after incubation. Lyons (1990) mentioned that one of the initial indicators used for assessment concentrates mainly on cost-benefit analysis. Furthermore, Markley and McNamara (1996), in their study on the performance of USA incubators, on the one hand, assessed both the economic and physical influence of the study area's economy, with part of the variables considered being; sales, payroll, and cost of goods, as well as other benefits, for example, jobs creation and income realization. On the other hand, Mian (1997) analyzed universities' incubator performance, using their sustainability and growth, tenant firm survival and growth, and contribution to the universities' mission. The number of jobs created and the sustainability of the organizations after graduation were the two sets of indicators used by the National Business Incubator Association (1997) to assess the performance of graduated firms, with findings reflecting that the most important indicators are job creation, along with several clients/ customers, and several graduates produced by the incubator.

Wanyoko (2013) argues that skills learned during the incubation period have less impact on businesses especially when businesses are unable to appropriately apply the skills learned during incubation. Therefore, one of the ways to ensure continuity and the impact of an incubation program is for incubated businesses to continue to operate and grow on their post-graduation. Below are some of the indicators that could be used to measure the success and impact of training and support received from an incubation program by SMEs.

\subsection{Profitability}

Profitability is one of the primary reasons an organization is established, as this allows them to gain a return on their investment for their stakeholders (Fatoki, 2014). Profit is achieved when a business can generate adequate cash to cater for all expenditure as and when required and still have excess funds. Certain financial calculations are used to unpack the financial position and performance of a business. When a business can achieve higher financial ratios it is considered successful, becoming an incentive for the entrepreneur to continue with the entrepreneurial initiative as it generates profit. Business failure happens when there are losses and the inability of a business to generate enough revenue to cater for its expenditures, resulting in the business closing down.

\subsection{Financial Resources}

Business growth and sustainability are largely dependent on the available financial resources required to run the operations of the organization. Strydom, et al. (2010) argued that finance alone cannot determine business success. Nonetheless, access to funding is important as a success factor because, when adequate funds are available for use by SMEs, there is a real possibility for success and the opportunity to compete both at local and global level, thus encouraging adequate investment in innovation and the technology required to improve the firm's productivity. Nevertheless, a small percentage of SMEs, according to Fatoki and Odeyemi (2010), able to meet the minimum requirements, can obtain loans from financial institutions, most especially the banks. Not having an adequate understanding of the minimum requirements for the processing and approving of loans pose major problems for the SMEs that can, however, be overcome through the incubators, who can help to develop the required documents 
needed to approach the banks for funds.

\subsection{Higher Sales}

Higher sales can be construed to mean a product or service results in a customer's satisfaction, with more sales likely to lead to more profit when resources are managed effectively. Therefore, higher sales is a measure of business success (Lekhanya \& Manson, 2014). Big businesses employ sales personnel to specifically deal with attracting customers and creating demand for their product. In reality, as a new start-up, almost the entire staff of a company may not have any knowledge or be aware of the products and services being rendered by the SMEs. As such, the role of marketing is an important tool to help introduce and advertise products to the public through various media (Iwu, 2009). One such is the use of marketing representatives or marketers, who can meet prospective customers and introduce the product and services to the market. Unfortunately, when marketing is not done correctly, a challenge may arise as to how the SMEs could make sales to make a profit, thus resulting in the organization being unable to sustain itself and remain in business for a longer period. Although, at inception, most SMEs have limited market coverage and a small customer base that could only be overcome through aggressive marketing (Van Scheers, 2011). It is important that a good marketing and sales strategy is put in place by the SMEs to help eliminate needless overheads. By realizing in time that it is important to harness a substantial part of the market, SMEs reduce the time to break even, which allows them to start making a profit, in effect setting up their sustainability.

\subsection{Increase in Employees}

One of the objectives of the National Policy on Development of SMEs in the Kingdom of Eswatini is the creation of employment opportunities by SMEs for indigenous SWAZIs (MCIT, 2014). SMEs are the main providers of employment, especially in developing countries (Ayyagari, Dermirguc-Kunt, \& Maksimovic, 2011, Nasr \& Rostom, 2013, Finscope, 2017). New jobs created result from expansion within a firm: one can thus say that an increase in the number of employees denotes a firm being successful. Some researchers (for example, Kesper, 2001, Nasr \&Rostom, 2013) argue that the reason SMEs can create jobs is because of an excess supply of unskilled labor. As a consequence, workers are then exploited by squeezing labor costs instead of firms upgrading to use technology. Unskilled labor generates low labor productivity, resulting in SME being vulnerable to competitors with less access to international markets. Yet, job creation is essential for a country and an individual's well-being. Receiving an income creates a sense of dignity for an individual that could result in lowering other social problems in the community, such as crime.

\section{Limitations}

Business incubation is gradually gaining recognition in most developing countries, in general, and more specifically, in the Kingdom of Eswatini. The literature on the subject is, however, negligible and, as such, most of the literature used for this analysis is largely dependent on research done in other developed and developing countries. Therefore, it is anticipated that an empirical study is carried out to help substantiate the findings in this article, which will assist to confirm the impact of SMEs training by BIs in the Kingdom of Eswatini, to verify whether this would help SMEs remain in business after take-off and enable them to remain sustainable and competitive for a longer period.

\section{Conclusion and Implications}

The themes emerging from this review have no doubt helped to unearth not only the importance but also the role played by BIs in ensuring start-up companies can remain in business once they begin operation after the incubation period. BIs assist SMEs to accelerate and systemizes the process of creating successful enterprises, by providing a competitive and integrated range of support including, incubator space, business support services, and clustering, as well as networking opportunities. This support will assist SMEs to be self-sustainable and to remain competitive over a long period, thus contributing to a nation's socio-economic development through job creation and employment.

While BIs face challenges limiting their operations it is, nonetheless, important to showcase BIs' role in a nation's local economic development through training and support rendered to SMEs. The Kingdom of Eswatini's SMEs are still faced with many sustainability issues that limit their existence, mainly due to the high rate of SMEs' failure in the country, which negatively impacts their ability to contribute towards job creation, poverty reduction, and economic growth. BIs are reported as being the vehicles for SMEs' success as they offer solutions to most problems faced by SMEs. Unfortunately, the failure rate of SMEs perhaps suggests that BIs are not necessarily living up to expectation as many SMEs still struggle to operate in the competitive business environment after graduating from an incubation program.

Therefore, it is assumed that most of these challenges faced by SMEs can be overcome through a more strategic partnership with BIs. To assist most SMEs to continue to remain in business and be competitive, BIs must continue 
to work with these incubated enterprises even after graduation. Wanyoko (2013) found the positive impact of post-graduation follow-up on an incubation program to enhance business sustainability and competitiveness. This shows the importance of a continued partnership between BIs and the incubated SMEs; this assistance would contribute to business growth. Furthermore, the main advantage of the relationship between BIs and incubated SMEs is the ability to help nurture the business to a point where it can stand on its own. Another advantage highlighted is the assistance in gaining access to the requisite capital to run the business. It is, therefore, important that the Kingdom of Eswatini's government helps to provide a conducive environment for businesses to thrive, while also assisting by providing more of an oversight role to help monitor PBIs activities, in a manner whereby this partnership can assist in fostering economic growth and poverty reduction.

Given the fact that SMEs are the engine for economic development and growth of a country, the Kingdom of Eswatini's government must set up more BIs that would support and grow the country's SMEs. Moreover, evidence from this analysis of existing literature shows that BIs can assist SMEs to become sustainable and competitive. Finally, it is suggested that an examination of available frameworks and policies from other successful countries be carried out by the government and other stakeholders, for the benefit of the Kingdom of Eswatini.

\section{References}

Abor, J., \& Quartey, P. (2010). Issues in SME Development in Ghana and South Africa. International Research Journal of Finance and Economics, (39).

Aernoudt, R. (2004). Incubators: tool for Entrepreneurship?. Small Business Economics, 23(2), 127-135.

Al-Mubaraki, H. M., \& Busler, M. (2011). The incubators economic indicators: Mixed approaches. Journal of Case Research in Business and Economics, 4, 1-12.

Arubayi, O. D. F. (2010). An Evaluation Study of Technoserve's Small Business Training Programme in Swaziland. Unpublished Master's thesis. Cape Town: University of Stellenbosch.

Ayyagari, M., Demirguc-Kunt, A., \& Maksimovic, V. (2011). Small vs. young firms across the world: contribution to employment, job creation, and growth. The World Bank. Retrieved from https://elibrary.worldbank.org/doi/abs/10.1596/1813-9450-5631

Barrow, C. (2001). Incubator: A Realist's Guide to the World's New Business Accelerators. John Wiley \& Sons Ltd., West Sussex, UK.

Bowen, M., Morara, M., \&Mureithi, S. (2009). Management of Business Challenges among Small Enterprises in Nairobi. KCA Journal of Business Management, 2(1).

Brown, M., Harrell, M. P., \& Regner, W. (2000). Internet Incubators: How to invest in the new economy without becoming an investment company. Business Lawyer, 56(1), 273-284.

Bruneel, J., Ratinho, T., Clarysse, B., \& Groen, A. (2012). The Evolution of Business Incubators: Comparing demand and supply of business incubation services across different incubator generations. Technovation, 32, $110-121$.

Business incubator. (2020). Business incubator in Entrepreneur's Small Business Encyclopedia. Retrieved from http://entrepreneur.com/encyclopedia/business-incubator

Cant, M. C., \& Wiid, J. A. (2013). Establishing the challenges affecting South African SMEs. The International Business \& Economics Research Journal, 12(6), 707.

Central Bank of Eswatini (CBE). (2019). Economic Activity. Retrieved from https://www.centralbank.org.sz/

Choto, P. (2015). The impact of business incubators on survivalist entrepreneurs in the Cape metropolitan area. Unpublished MTech thesis. Cape Town: Cape Peninsula University of Technology.

Cronin, P., Ryan, F., \& Coughlan, M. (2008). Undertaking a literature review: A step by- step approach. British Journal of Nursing, 17(1), 38-43.

Dlamini, M. P., Masuku, M. B., \& Dlamini, B. M. (2008). Entrepreneurs' business facts and formal support utilised in Swaziland. Association for International Agriculture and Extension Education, 112-124.

Dlamini, M. S. (2018). Presentation on SME Development in Swaziland.

Dlamini, Z. C. (2016). An assessment of entrepreneurial conditions within Swaziland's national SME policy and an evaluation of their impact on venture growth. Unpublished master's degree thesis. Johannesburg: University of Witwatersrand. 
ESWADE. (2019). Eswatini water and agriculture enterprise (ESWADE). Retrieved from http://www.seadw.co.sz

European Commission. (2010). Internationalisation of SMEs. DG Enterprise and Industry. European Commission: Brussels. Retrieved from www.ec.europa.eu/enterprise/e_i/index_en.htm

Fatoki, O. (2014). The causes of the failure of new small and medium enterprises in South Africa. Mediterranean Journal of Social Sciences, 5(20), 922.

Fatoki, O., \& Odeyemi, A. (2010). Which new small and medium enterprises in South Africa have access to bank credit?. International Journal of Business and Management, 5(10), 128.

Fernández Fernández, M. T., \& Blanco Jiménez, F. J. (2011). Incubación de empresas y softlanding empresarial en países socios mediterráneos. Información Comercial Española, Revista de Economía, 861, 161-174.

Fernández Fernández, M. T., Blanco Jiménez, F. J., \& J Cuadrado Roura, J. R. (2015). Business incubation: innovative services in an entrepreneurship ecosystem, The Service Industries Journal, 35(14), 783-800.

Finscope Swaziland. (2017). Micro, small and medium enterprises (MSME) survey. Retrieved from http://www.finmark.org.za/wp-content/uploads/2017/08/finscope-swaziland-pocket-guide_en.pdf

Grimaldi, R., \& Grandi, A. (2003). Business incubators and new venture creation: an assessment of incubating models. Technovation, 25, 111-121 (2005).

Gwija, S. A., Eresia-Eke, C. E., \& Iwu, C. G. (2014). Challenges and Prospects of Youth Entrepreneurship Development in a Designated Community in the Western Cape, South Africa. Journal of Economics and Behavioral Studies, 6(1), 10-20.

Hansen, M. T., Chesbrough, H. W., Nohria, N., \& Sull, D. (2000). Networked incubators. Harvard Business Review, 78(5), 74-84.

Hlatshwako, P. L. (2012). Challenges facing small and medium enterprises in Manzini, Swaziland. Unpublished master's thesis. Kwazulu-Natal: University of KwaZulu-Natal.

Hughes, M. H., Ireland, H., \&Morgan, R. E. (2007). Stimulating dynamic value: Social capital and business incubation as a path way to competitive success. Long Range Planning, 40(2), 154-177.

Iwu, C. G. (2018). The sustainability of small or medium enterprises growth in emerging markets. In Proceedings of the International Conference on Business and Management Dynamics (ICBMD) (pp. 213-221).

Iwu, CG. (2009). What is marketing? CustomerThink, March 5. Retrieved 27 June 2020, from https://customerthink.com/209180/

Kesper, A. (2001). April. Failing or not aiming to grow? Manufacturing SMMEs and their contribution to employment growth in South Africa. In Urban Forum, 12(2), 171-203, Springer-Verlag.

Koshy, P. (2010). Role and relevance of business incubators in ICT led global educational system: case for eco-enterprise village. Institute for Development Studies and Enterprise Research (IDSER). Retrieved from http://mpra.ub.uni-muenchen.de/27311/

Lekhanya, L. M., \&Mason, R. B. (2014). Selected Key External Factors Influencing the Success of Rural Small and Medium Enterprises in South Africa. Journal of Enterprising Culture, 22(3), 331-348.

Lesáková, L. (2012). The Role of Business Incubators in Supporting the SME Start-up. Acta Polytechnica Hungarica, $9(3)$.

Lose, T., \& Tengeh, R. K. (2015). The sustainability and challenges of business incubators in the Western Cape Province, South Africa. Sustainability, 7(10), 14344-14357.

Mahmood, N., Jianfeng, C., Munir, H., Yanran, M., \& Cai, Y. (2016). Incubators, SMEs, and Economic Development of China. International Journal of Multimedia and Ubiquitous Engineering, 1(1), 311-318.

Makhubu, M. (2017). Start-ups need mentorship to succeed. Swazi Observer, February 8.

Markley, D. M., \&McNamara, K. T. (1996). Local Impact and Fiscal Impacts of Business Incubators. State and Local Government Review, 28(1), 17-27.

Masutha, M., \& Rogerson, C. M. (2014). Small business incubators: An emerging phenomenon in South Africa's SMME economy. Urbani Izziv, 25 (Special Issue), S47-S62.

Menzies, D. (2019, January 9). Skills gap a hindrance to funding for SMEs. 9 January. Retrieved from 
http://www.moneyweb.co.za

Mian, S. A. (1997). Assessing and Managing the University Technology Business Incubator: An Integrative Framework. Journal of Business Venturing, 12(4), 251-285.

Nasr, S., \& Rostom, A. (2013). SME contributions to employment, job creation, and growth in the Arab world. The World Bank.

National Business Incubation Association [NBIA]. (1997). Industry facts and figures. Athens, OH, 45701-3571.

National Business Incubation Association [NBIA]. (2001). Best practice in action: Guidelines for implementing first class business incubation programs. Athens, $\mathrm{OH}$ : Author.

National Business Incubation Association [NBIA]. (2014). The History of Business Incubation. Retrieved from http://www.nbia.org/resource_library/history/index.php

Niammuad, D., Mapompech, K., \& Suwanmaneepong, S. (2014). Entrepreneurship Product Innovation. A second order factor analysis. The Journal of Applied Business Research, 30(1), 197-120.

Ogutu, V. O., \& Kihonge, E. (2016, May). Impact of business incubators on economic growth and entrepreneurship development. International Journal of Science and Research (IJSR), 5(5), 231-241.

Opute, A. P., Irene, B. N., \& Iwu, C. G. (2020). Tourism service and digital technologies: A value creation perspective. African Journal of Hospitality, Tourism and Leisure, 9(2).

Organisation for Economic Co-Operation Development [OECD]. (1997). Technology Incubators: Nurturing Small Firms. OECD, Paris.

Organisation for Economic Co-Operation Development [OECD]. (1999). Business Incubation: International Case Studies. OECD Publishing, Paris. https://doi.org/10.1787/9789264173781-en

Royal Science \& Technology Park [RSTP]. (2019). The kingdom of Eswatini business incubation report January 2019. Retrieved from https://rstp.org.sz/it-business-incubation/

Sanyal, S., \& Hisamic, M. (2018, September). The Role of Business Incubators in Creating an Entrepreneurial Ecosystem: A Study of the Sultanate of Oman. Indian Journal of Commerce \& Management Studies, IX(3), 10-17.

Schwartz, M., \& Hornych, C. (2010). Cooperation patterns of incubator firms and the impact of incubator specialization: Empirical evidence from Germany. Technovation, 30(9), 485-495.

Sebenzile. (2018, May). Business Incubation. Royal Science Technology Park.

SEDCO. (2019). Small Enterprise Development Company. Retrieved from http://www.sedco.biz

Sherman, H., \& Chappell, D. S. (1998). Methodological challenges in evaluating business incubator outcomes. Economic Development Quarterly, 12(4), 313-321.

Sin, K. C. (2010). The success stories of Malaysian SMEs in promoting and penetrating global markets through business competitiveness strategies. Asia Research Centre, CBS, Copenhagen Discussion Papers, p. 33.

Snyder, H. (2019). Literature review as a research methodology: An overview and guidelines. Journal of Business Research, 104, 333-339.

St. John, K., \& McNeal, K. S. (2017). The Strength of Evidence Pyramid: One Approach for Characterizing the Strength of Evidence of Geoscience Education Research (GER) Community Claims. Journal of Geoscience Education, 65(4), 363-372.

Strauss, A., \& Corbin, J. (1998). Basics of Qualitative Research: Techniques and Procedures for Developing Grounded Theory (2nd ed.). Sage, Thousand Oaks, CA.

Strydom, J., Ferreira, E., \& Nieuwenhuizen, C. (2010). The process of business assistance to small and medium enterprises in South Africa: preliminary findings. Journal of Contemporary Management, 7(1), 94-109.

Swaziland development finance corporation [FINCORP] limited and its subsidiary. (2014). Annual Report 2014. Retrieved

from http://www.fincorp.co.sz/wp-content/uploads/2019/04/fincorpannualreport2014_final_compressed.pdf

Swaziland Ministry of Commerce, Industry and Trade [MCIT]. (2006). National policy on the development of small and medium enterprises. Mbabane. 
Swaziland Ministry of Commerce, Industry and Trade [MCIT]. (2014). Swaziland National Development Strategy. Mbabane.

UNESCO. (2019). United Nations Education Scientific and Cultural Organization, 14 March 2019.

Unger, J. M., Rauch, A., Frese, M., \& Rosenbusch, N. (2011). Human capital and entrepreneurial success: a meta-analytical review. Journal of Business Venturing, 26(3), 341-358.

Van der Zee, P. (2007). Business incubators contribution to the development of businesses in the early stages of the business life cycle. Unpublished Masters thesis, University of Pretoria.

Van Scheers, M. L. (2011). SMEs' marketing skills challenges in South Africa. Retrieved from https://www.semanticscholar.org/paper/SMEs\%27-marketing-skills-challenges-in-South-Africa-Scheers/cb9799 833e395953098714183426b9a54ebefd75

Wanyoko, A. M. (2013). Influence of business incubation services on the growth of Small and Medium Enterprises in Kenya. International Journal of Social Sciences and Entrepreneurship, 1(7), 454-468.

\section{Note}

Note 1. The Kingdom of Eswatini is the new name for Swaziland, a country in Southern Africa

\section{Copyrights}

Copyright for this article is retained by the author(s), with first publication rights granted to the journal.

This is an open-access article distributed under the terms and conditions of the Creative Commons Attribution license (http://creativecommons.org/licenses/by/4.0/). 